\title{
Expression of the ets-1 Proto-Oncogene in Human Colorectal Carcinoma
}

Toshiyuki Nakayama, M.D., Masahiro Ito, M.D., Akira Ohtsuru, M.D., Shinji Naito, M.D., Ichiro Sekine, M.D.

Department of Molecular Pathology (TN, MI, IS), Department of Nature Medicine (AO), and Tissue and Histopathology Section (SN), Division of Scientific Data Registry, Nagasaki University School of Medicine, 1-12-4 Sakamoto, Nagasaki, Japan

The proto-oncogene, ets-1, is a transcription factor known to control the expression of a number of genes involved in extracellular matrix remodeling and has been postulated to play a role in cell migration and tumor invasion. To elucidate the involvement of ets-1 in human colorectal carcinomas, we examined 41 cases of colorectal adenoma and 122 cases of colorectal carcinoma by immunohistochemistry and compared the degree of Ets- 1 expression with the depth of carcinoma invasion. In adenomas, 12 of 41 cases $(29.3 \%)$ showed immunopositivity for Ets-1. 12 of 27 cases (44.4\%) of adenoma with high grade dysplasia showed immunopositivity for Ets-1. However, there was no positive case in low or moderate dysplasia of adenoma. In contrast, 103 of 122 cases $(84.4 \%)$ of colorectal adenocarcinoma showed immunoreactivity for Ets-1 in the carcinoma cells themselves. We investigated the relationship between pathological features in colorectal carcinoma and Ets-1 immunoreactivity of the tumor cells. Among the 122 cases of invasive carcinomas, Ets-1 immunoreactivity was significantly correlated with the depth grading of tumor invasion $(P<.0001)$, the presence of lymph node metastasis $(P<.05)$, lymphatic invasion $(P<.01)$ and venous invasion $(P<.05)$. However, Ets-1 expression did not correlate with histological differentiation. In situ hybridization also confirmed the presence of ets-1 mRNA in colorectal carcinomas. Expression of ets-1 mRNA was also detected in two of three human colorectal carcinoma tissues and in four of six different kinds of carcinoma cell lines by the reverse transcription polymerase chain reaction method. These findings suggest that the expression

Copyright () 2001 by The United States and Canadian Academy of Pathology, Inc.

VOL. 14, NO. 5, P. 415, 2001 Printed in the U.S.A.

Date of acceptance: January 8, 2001.

Address reprint requests to: Toshiyuki Nakayama, M.D., Department of Molecular Pathology, Nagasaki University School of Medicine, 1-12-4 Sakamoto, Nagasaki 852-8523, Japan; e-mail: toshi-n@net.nagasakiu.ac.jp; fax: 81-95-849-7108. of Ets-1 is one of the important factors related to carcinogenesis and/or tumor invasion of colorectal carcinoma.

KEY WORDS: Colorectal carcinoma, ets-1, Immunohistochemistry, In situ hybridization.

Mod Pathol 2001;14(5):415-422

The prognosis of colorectal cancer patients is based on the depth of invasion and the presence of lymph node metastasis. Usually, these parameters can be determined by microscopic examination of tissue sections from the primary neoplasm and lymph nodes (1). However, only histopathological examination of primary colorectal carcinoma specimens cannot always elucidate the prognosis (1). Recently, the occurrence and progression of cancer is suggested to be related to a series of genetic events affecting the structure and/or the expression of a number of oncogenes, anti-oncogenes and growth factors. However, the mechanism of the invasion of colorectal carcinomas has not been fully elucidated.

ets- 1 was originally characterized as a $\nu$-ets retroviral gene, 1 of the 2 oncogenes ( $\nu$-myb and $v$-ets) of the avian leukemia retrovirus, E26 (2). The ets family of genes encodes transcription factors for mesodermal cell development during the embryonal period (3). Ets-1 plays a role in the regulation of physiological processes such as cell proliferation and differentiation (4). Ets-1 is also associated with invasive processes in the stromal tissues of human carcinomas (5). We have reported that Ets- 1 is correlated with the progression of the carcinoma cells of the stomach (6), pancreas (7) and thyroid (8). However, the biological function of the ets-1 protooncogene remains unknown. The processes of tumor invasion and metastasis are thought to depend on the increased proteolytic activity of the invading tumor cells (9). Matrix metalloproteinases and plasminogen activator have been proposed to participate in the metastatic cascade (9-11). Ets-1 protein interacts with the urokinase-type plasminogen ac- 
tivator (u-PA) gene enhancer and with the promoters of the stromelysin-1 and matrix metalloproteinase-1(MMP-1) genes $(5,12)$. Ets- 1 , therefore, is suggested to regulate increased tumor invasion by activating the expression of u-PA, stromelysin and collagenase. Based on these findings, we hypothesized that ets-1 may be involved in the progression and/or the invasion of colorectal carcinomas.

The purpose of the present study was to evaluate the role of ets-1 in the carcinogenesis and/or the invasion of human colorectal carcinoma.

\section{MATERIALS AND METHODS}

\section{Cases and Tissues}

We studied 41 colorectal adenomas and 122 primary human colorectal adenocarcinomas. All specimens of adenoma had been resected by endoscopy and all specimens of adenocarcinoma were obtained from patients operated on at Nagasaki University Hospital between 1996 and 1999. Each tumor was assigned a histological type according to the World Health Organization classification (13) and a depth grading of infiltration according to the TNM staging system by the American Joint Commission on Cancer (14). Fifteen specimens of normal colon mucosal tissue, that were taken from patients without colorectal cancer, were evaluated as the normal control.

The desmoplastic stromal reaction was graded according to the extent of the stromal area involved. It was defined as "slight" (when the fibrous stromal area was less than $25 \%$ of the whole tumor), "moderate" (between 25 and 50\%), and "extensive" (when it exceeded $75 \%$ of the whole tumor) based on the overall pattern (15). The examination was performed on routine slides to identify lymphatic, venous and perineural invasion. In addition to hematoxylin and eosin staining, we also used Elastica van Gieson stain in all cases. Each parameter was defined as "present" when invasion was identified with certainty, but defined as "absent" when either not observed at all or not observed with certainty $(16,17)$. Lymph node metastasis was defined as "present" only when histologically proven. Diagnosis was established by two independent pathologists (TN, MI), and cases of questionable diagnosis were omitted from the study.

\section{Immunohistochemistry}

Formalin-fixed and paraffin-embedded tissues were cut into $4 \mu \mathrm{m}$ sections, deparaffinized in xylene and rehydrated in phosphate-buffered saline. Deparaffinized sections were preincubated with normal bovine serum to prevent nonspecific binding, and then incubated overnight at $4^{\circ} \mathrm{C}$ with an optimal dilution $(0.1 \mu \mathrm{g} / \mathrm{mL})$ of a primary polyclonal antibody against human Ets-1 (C-20, raised against the C-terminal domain of the Ets-1 protein; Santa Cruz Biotechnology, Inc., Santa Cruz, CA) (18). The slides were sequentially incubated with an alkaline phosphatase-conjugated horse antirabbit immunoglobulin antibody, and the reaction products were resolved using a mixture of 5-bromo-4chloro-3-indolyl phosphate and nitroblue tetrazolium chloride (BCIP/NBT; BRL, Gaithersberg, MD). Preabsorption of the primary antibody with excess recombinant ets-1 peptide (Santa Cruz Biotechnology, Inc.) was used as a negative control. Adrenal gland tissue (3) served as the internal positive control for Ets-1 immunostaining. Analysis of the immunohistochemical staining was performed by two investigators (TN, MI). Ets-1 expression was classified into three categories, depending on the percentage of cells stained:,- 0 to $10 \%$ positive cells; ,+ 10 to $50 \%$ positive tumor cells; and ++ , more than $50 \%$ positive tumor cells.

\section{In Situ Hybridization}

In situ hybridization for the detection of human ets-1 mRNA was performed using an oligonucleotide probe complementary to a fragment of human ets-1 mRNA (19). The sequence of the oligonucleotide probe is 5'-GCCCAGCTTCATCACAGAGTCCTA TCAGAC-3', and it does not cross-hybridize with other mRNA sequences. The probe was labeled with 5' tailed digoxigenin (DIG, Greiner Japan, Inc., Tokyo, Japan) and purified by high performance liquid chromatography. Four cases of human colorectal adenocarcinoma were studied by in situ hybridization. In all of these cases, we were able to obtain relatively fresh (within 6 months) paraffin embedded sections. The presence of cytoplasmic RNA was confirmed through the use of a methyl green pyronine staining solution (Muto Pure Chemicals, Tokyo, Japan). Prehybridization was carried out as described previously (20). The sections were treated with $0.2 \mathrm{~N} \mathrm{HCl}$ for 20 minutes and digested with $100 \mu \mathrm{g} / \mathrm{mL}$ of proteinase K (Sigma, St. Louis, MO) for 10 minutes at $37^{\circ} \mathrm{C}$. After postfixation in $4 \%$ paraformaldehyde, each section was covered with $20 \mu \mathrm{L}$ of a denatured hybridization mixture containing 4\% dextran sulfate, 125 $\mu \mathrm{g} / \mathrm{mL}$ sonicated salmon sperm DNA, $9 \%$ deionized formamide, $2.5 \mu \mathrm{g} / \mathrm{mL}$ yeast tRNA, $5 \times$ Denhardt's medium, 1 mм EDTA (ethylenediamine-tetraacetic acid, $\mathrm{pH}$ 7.4), $0.6 \mathrm{~m} \mathrm{NaCl}, 10 \mathrm{~mm}$ Tris- $\mathrm{HCl}$, and 1 $\mu \mathrm{g} / \mathrm{mL}$ digoxigenin-labeled Ets-1 oligonucleotide probe, and placed in a moist chamber, where it was incubated at $37^{\circ} \mathrm{C}$ for 15 hours. After washing, in situ detection was accomplished with a DIG detection kit (GIBCO/BRL). Briefly, the slides were incubated with $100 \mu \mathrm{L}$ of blocking solution for $15 \mathrm{~min}$ 
at room temperature and incubated with the streptavidin-alkaline phosphatase complex. ets-1 mRNA expression was evaluated by comparing alkaline phosphatase staining using BCIP/NBT with the results obtained from the positive and negative controls. Each slide was studied in duplicate and negative controls were made using the digoxigeninlabeled sense oligoprobe (5'-GTCTGATAGGACTCTG TGATGAAGCTGGGC-3'). RNase treatment was carried out before hybridization as another negative control. Slides of a human adrenal gland served as a positive control (3).

\section{Cell Culture}

Six human colorectal carcinoma cell lines LoVo (poorly differentiated adenocarcinoma), DLD-1 (adenocarcinoma), WiDr (adenocarcinoma), Colo 201 (adenocarcinoma), Colo 320 (adenocarcino$\mathrm{ma}$ ), and Sw 837 (adenocarcinoma) (21-26), were incubated at $37^{\circ} \mathrm{C}$ in a humidified atmosphere of $5 \% \mathrm{CO}_{2}$ and $95 \%$ air. Cultures of LoVo and Colo 201 were maintained in RPMI medium 1640 (GIBCO/ BRL, Grand Island, NY) supplemented with $10 \%$ fetal calf serum $(21,22)$. DLD-1 was maintained in DMEM/F-12 (GIBCO/BRL) supplemented with $10 \%$ fetal calf serum (23). WiDr was maintained in Dulbecco's modified Eagle's medium (DMEM, GIBCO/ BRL) supplemented with $10 \%$ fetal calf serum (GIBCO/BRL) (24). Colo 320 was maintained in RPMI 1640 medium (GIBCO/BRL) supplemented with $10 \%$ fetal calf serum (25) and Sw 837 was maintained in modified L-15 medium with $10 \%$ fetal calf serum (26). Plastic culture dishes were purchased from Becton Dickinson (Oxnard, CA). All of these cells were provided by the Health Science Research Resources Bank (Osaka, Japan).

\section{Reverse Transcription-Polymerase Chain Reaction (RT-PCR)}

Total RNA was prepared from three human colorectal carcinoma tissues and the carcinoma cell lines Lovo, DLD-1, WiDr, Colo 201, Colo 320 and Sw 837 (21-26) using the acid guanidine phenol method (27).

Cellular RNA ( $1 \mu \mathrm{g})$ was incubated at $37^{\circ} \mathrm{C}$ for 1 hour in $50 \mu \mathrm{L}$ of reverse transcriptase buffer containing 20 units of RNAsin (Promega Corp., Madison, WI), 100 pmol of random hexamer primers (Boehringer Mannheim, Mannheim, Germany), and 400 units of Moloney murine leukemic virus reverse transcriptase (GIBCO/BRL). Reverse transcription was terminated by heating at $95^{\circ} \mathrm{C}$ for 10 minutes, and $20 \%$ of the resultant cDNA was removed for PCR. PCR samples were incubated with 50 pmol of each primer and 2.5 units of Taq DNA polymerase. The human ets-1 PCR primers were
5'-GGGTGACGACTTCTTGTTTG-3' (sense) and 5'GTTAATGGAGTCAACCCAGC-3' (antisense). The human $\$$-actin PCR primers were 5'-TCCTCCCTG GAGAAGACTA-3' (sense) and 5'-AGTACTTGCG CTCAGGAGGA-3' (antisense). The ets- 1 and $\beta$-actin primers were predicted to amplify 274 and $313 \mathrm{bp}$ DNA fragments, respectively. Both primer pairs were chosen to span introns of their respective human genes. Samples were subjected to 28 cycles of PCR amplification using a thermocycler. Each cycle included denaturation at $94^{\circ} \mathrm{C}$ for 1 minute, annealing at $57^{\circ} \mathrm{C}$ for 1 minute, and primer extension at $72^{\circ} \mathrm{C}$ for 1.5 minutes. An aliquot of each amplification mixture was subjected to electrophoresis on a $1.5 \%$ agarose gel, and DNA was visualized by ethidium bromide staining.

\section{Statistical Analysis}

The Stat View II program (Abacus Concepts, Inc., Berkeley, CA) was used for statistical analyses. Analyses comparing the intensities of Ets- 1 expression were performed by the Mann-Whitney and Spearman's tests.

\section{RESULTS}

Of the 122 primary human colorectal adenocarcinomas there were 17 submucosal infiltrative carcinomas (T1), 12 carcinomas invading proprial muscle layers (T2), 82 carcinomas reaching the subserosa (T3), and 11 carcinomas through serosa or invading contiguous organs (T4). Histologically, of the 122 primary human colorectal adenocarcinomas, there were 41 well differentiated adenocarcinomas, 66 moderately differentiated adenocarcinomas, 8 poorly differentiated adenocarcinomas, 7 mucinous adenocarcinomas. The 27 specimens of adenoma with high grade dysplasia (Tis) and the 14 specimens of adenomas with low or moderate grade dysplasia had been resected by endoscopy.

The results of immunohistochemical staining are summarized in Tables 1 and 2. In Table 1, Ets-1 antigen was expressed heterogeneously in adenomas and carcinomas. Strong staining of Ets-1 was observed in $84.4 \%$ of the carcinomas (103 of 122) and there was significant differences between total adenocarcinoma and adenoma/normal mucosa, respectively $(P<.01)$. In adenomas, 12 of 41 cases (29.3\%) showed immunopositivity for Ets-1. Twenteen of 27 cases $(44.4 \%)$ with high grade dysplasia of adenoma (Tis) showed immunopositivity for Ets-1. However, there was no positive case in 14 cases with low or moderate dysplasia of adenoma. There was significant difference in Ets-1 expressions with between high grade dysplasia and low/moderate dysplasia of adenomas $(P<.01)$. And all 15 cases of normal mucosa were negative for Ets- 1 . 


\begin{tabular}{|c|c|c|c|c|c|}
\hline & \multirow{2}{*}{$n$} & \multicolumn{3}{|c|}{ Ets-1 Expression, $n(\%)$} & \multirow{2}{*}{ Note } \\
\hline & & - & + & ++ & \\
\hline Invasive carcinoma (T1-4) & 122 & $19(15.6)$ & $30(24.6)$ & $73(59.8)$ & $a$ \\
\hline Adenoma & 41 & $29(70.7)$ & $4(9.8)$ & $8(19.5)$ & \\
\hline High-grade dysplasia (Tis) & 27 & $15(55.6)$ & $4(14.8)^{c}$ & $8(29.6)^{c}$ & $b$ \\
\hline Low- or moderate-grade dysplasia & 14 & $14(100.0)$ & $0(0.0)$ & $0(0.0)$ & \\
\hline Normal mucosa & 15 & $15(100.0)$ & $0(0.0)$ & $0(0.0)$ & \\
\hline
\end{tabular}

${ }^{a}$ Significant differences between total adenocarcinoma and adenoma/normal mucosa, respectively $(P<0.01)$.

${ }^{b}$ Significant differences between high-grade dysplasia and low/moderate dysplasia of adenoma, respectively. $(P<0.01)$.

${ }^{c}$ Ets-1 was expressed in only high-grade dysplastic area of adenoma.

Ets-1 immunoreactivity of tumor cells in relation to pathological features in invasive carcinomas is shown in Table 2. Every type of colorectal carcinomas stained strongly for Ets-1. Ets-1 expression was found in $75.6 \%(31 / 41)$ of well-differentiated adenocarcinomas, $87.9 \%(58 / 66)$ of moderately differentiated adenocarcinomas, $100.0 \%(8 / 8)$ of poorly differentiated adenocarcinomas and $85.7 \%$ (6/7) of mucinous carcinomas. There were no statistical correlations in between Ets-1 immunoreactivity and the differentiation of colorectal carcinomas.

Ets-1 immunoreactivity was compared with the depth grading of tumor invasion. Ets-1 expression was found in $41.2 \%(7 / 17)$ of $\mathrm{T} 1$ tumor, in $83.3 \%$ (10/12) of T2 tumor, in $92.7 \%(76 / 82)$ of T3 tumor, and in $90.9 \%(10 / 11)$ of T4 tumor, respectively. A

TABLE 2. Ets-1 Expression in Colorectal Tumor (122 Cases)

\begin{tabular}{|c|c|c|c|c|}
\hline & \multirow{2}{*}{$n$} & \multicolumn{3}{|c|}{ Ets-1 Expression, $n(\%)$} \\
\hline & & - & + & ++ \\
\hline Total Adenocarcinoma & 122 & $19(15.6)$ & $30(24.6)$ & $73(59.8)$ \\
\hline \multicolumn{5}{|c|}{ Histological Differentiation } \\
\hline Well & 41 & $10(24.4)$ & $8(19.5)$ & $23(56.1)$ \\
\hline Moderate & 66 & $8(12.1)$ & $18(27.3)$ & $40(60.6)$ \\
\hline Poor & 8 & $0(0.0)$ & $3(37.5)$ & $5(62.5)$ \\
\hline Mucinous carcinoma & 7 & $1(14.3)$ & $1(14.3)$ & $5(71.4)$ \\
\hline \multicolumn{5}{|l|}{ Invasive grade $^{a}$} \\
\hline $\mathrm{T} 1$ & 17 & $10(58.8)$ & $4(23.5)$ & $3(17.6)$ \\
\hline $\mathrm{T} 2$ & 12 & $2(16.7)$ & $5(41.7)$ & $5(41.7)$ \\
\hline T3 & 82 & $6(7.3)$ & $19(23.2)$ & $57(69.5)$ \\
\hline $\mathrm{T} 4$ & 11 & $1(9.1)$ & $2(18.2)$ & $8(72.7)$ \\
\hline \multicolumn{5}{|c|}{ Desmoplastic stromal reaction $^{b}$} \\
\hline Slight & 27 & 7 (25.9) & $8(29.6)$ & $12(44.4)$ \\
\hline Moderate & 65 & $9(13.8)$ & $16(24.6)$ & $40(61.5)$ \\
\hline Extensive & 30 & $3(10.0)$ & $6(20.0)$ & $21(70.0)$ \\
\hline \multicolumn{5}{|l|}{ Lymph node metastasis ${ }^{c}$} \\
\hline Absent & 72 & $18(25.0)$ & $14(19.4)$ & $40(55.6)$ \\
\hline Present & 50 & $1(2.0)$ & $16(32.0)$ & $33(66.0)$ \\
\hline \multicolumn{5}{|l|}{ Lymphatic invasion $^{d}$} \\
\hline Absent & 26 & $9(34.6)$ & $8(30.8)$ & $9(34.6)$ \\
\hline Present & 96 & $10(10.4)$ & $22(22.9)$ & $64(66.7)$ \\
\hline \multicolumn{5}{|l|}{ Venous invasion $^{e}$} \\
\hline Absent & 67 & $14(20.9)$ & $19(28.4)$ & $34(50.8)$ \\
\hline Present & 55 & $5(9.1)$ & $11(20.0)$ & $39(70.9)$ \\
\hline \multicolumn{5}{|l|}{ Perineural invasion } \\
\hline Absent & 97 & $16(16.5)$ & $25(25.8)$ & $56(57.7)$ \\
\hline Present & 25 & $3(12.0)$ & $5(20.0)$ & $17(68.0)$ \\
\hline
\end{tabular}

${ }^{a} P<0.0001$, Spearman's test.

${ }^{b} P<0.05$, Spearman's test.

${ }^{c} P<0.05$, Mann-Whitney $U$ test.

${ }^{d} P<0.01$, Mann-Whitney $U$ test.

${ }^{e} P<0.05$, Mann-Whitney $U$ test. significant correlation was found between Ets-1 immunoreactivity and the depth grading of tumor invasion $(P<.0001)$.

The relationship between Ets-1 immunoreactivity of the tumor cells and the desmoplastic stromal reaction were investigated. There were significant associations between Ets- 1 immunoreactivity and the stromal reactions $(P<.05)$.

The incidence of lymph node metastasis, lymphatic invasion, venous invasion, and perineural invasion was $36.1 \%, 78.7 \%, 45.1 \%$ and $20.5 \%$, respectively. Ets- 1 immunoreactivity was significantly correlated with the presence of lymph node metastasis $(P<.05)$, lymphatic invasion $(P<.01)$ and venous invasion $(P<.05)$. However, there was no correlation between Ets-1 expressions and the perineural invasion.

Also, the invasive front and/or the peripheral parts of the primary tumor were intensely stained compared with the superficial and central parts of the tumor in almost all cases of invasive carcinomas.

Figure $1 \mathrm{~A}$ and $\mathrm{B}$ show a representative example of strong immunohistochemical Ets-1 staining in a carcinoma invading the subserosa. Ets-1 protein was detected in both the cytoplasm and the nucleus of almost all carcinomas (Fig. 1A). In a few cases, Ets-1 protein was predominantly located in the nucleus (Fig. 1B). Figure 1C and D show the adenoma with high grade dysplasia. Ets-1 was expressed only in the area with high grade dysplasia, but not in area with moderate or low grade dysplasia (Fig. 1D).

As with the antigenic intensity shown by immunostaining, ets-1 mRNA expression demonstrated by in situ hybridization was positive in both the cytoplasm and the nucleus of colorectal adenocarcinomas (Fig. 1E). And there are correlative expression of Ets-1 in between in situ hybridization and immunohistochemistry (Fig. 1F). No specific hybridization was observed with the sense labeled probe. RNase treatment of the sections hybridized with the Ets-1 oligonucleotide probe yielded no positive signals.

The results from RT-PCR of ets-1 mRNA in human colorectal cancer tissues and carcinoma cell lines are shown in Figure 2. Two of three human 

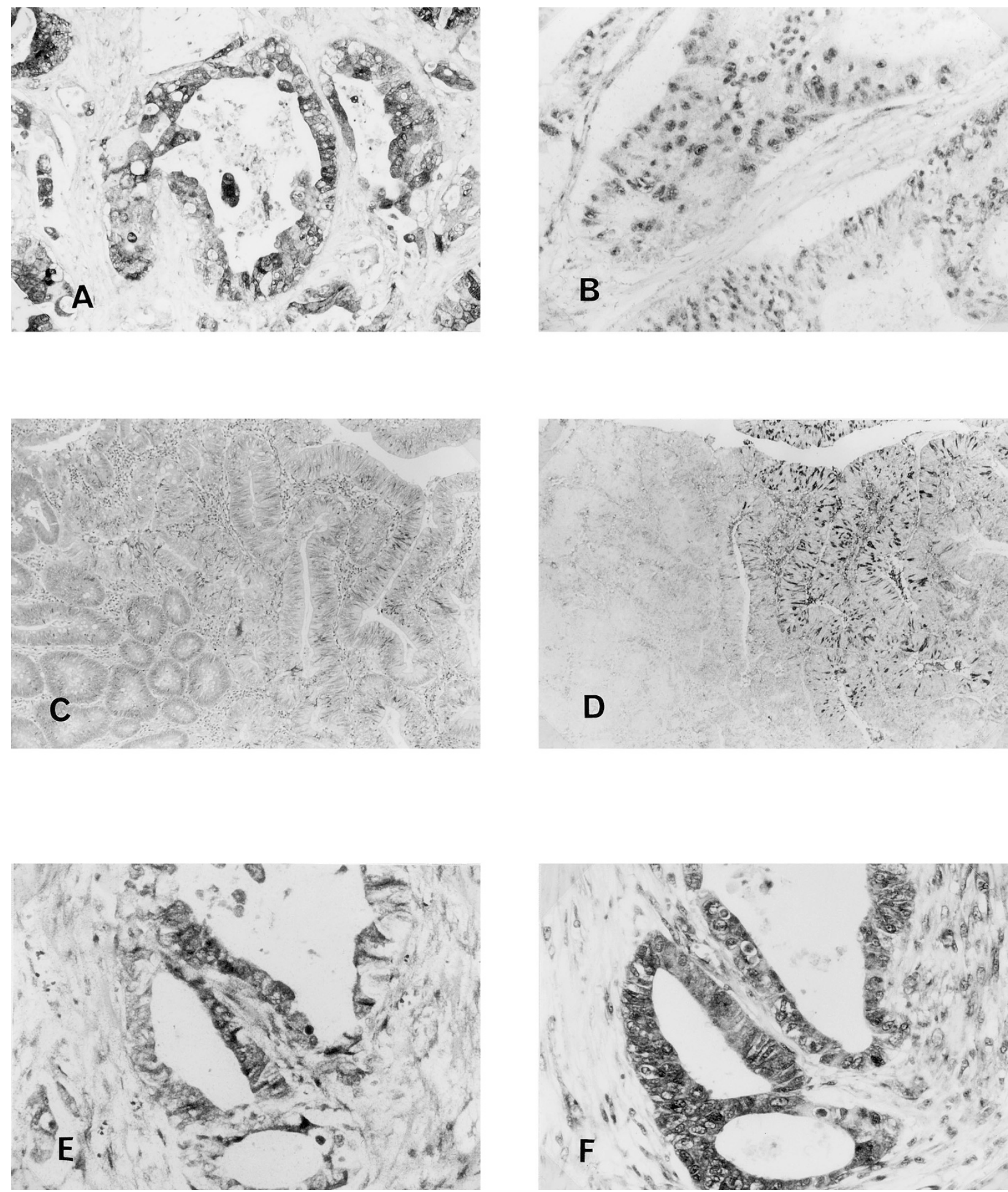

FIGURE 1. Immunohistochemical studies of Ets-1 reveals positive staining in cytoplasm and nucleus in human colorectal carcinoma cells (A). Ets1 protein is located predominantly in the nucleus (B). Hematoxylin-eosin staining of polypoid neoplasia in the human colon (C). Left area of this figure shows adenoma with moderate grade dysplasia and right area shows adenoma with high grade dysplasia. Immunohistochemical studies of Ets-1 reveal positivity only for the area of adenoma with high grade dysplasia, but not for the area of adenoma with moderate dysplasia (D). Using the in situ hybridization method, ets-1 mRNA is expressed in cytoplasm of carcinoma cells (E) and showing the immunohistochemical staining in same area of in situ hybridization for comparison (F). Immunoalkaline phosphatase staining; magnification: A, 100×; B, 200×; D, 60×; E, 200×; F, $200 \times$. And hematoxylin-eosin staining; magnification: C, $60 \times$.

colorectal carcinoma tissues and four carcinoma cell lines (Lovo, WiDr, Colo 201 and Sw 837) expressed ets-1 mRNA. However, one cancer tissue and two cell lines (DLD-1 and Colo 320) did not express ets- 1 mRNA. $\beta$-actin mRNA, a control to demonstrate the equivalent amounts of tissue RNA, was used for cDNA synthesis and was detected in all samples. 
A

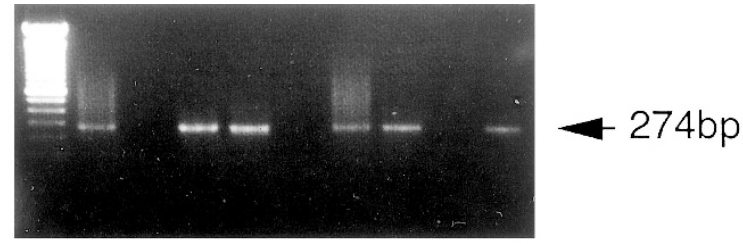

B

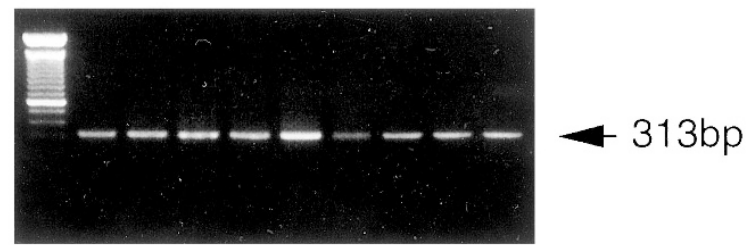

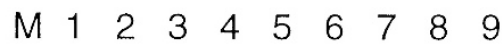

FIGURE 2. RT-PCR analysis of ets-1 mRNA expression in human colon carcinoma cells using the specific primer pairs predicted to amplify fragment size on the right (A, Ets-1, B, $\beta$-actin as internal control). Total RNA was prepared from three human colorectal carcinoma tissues (Lanes 1-3) and six carcinoma cell lines (Lane 4, Lovo; Lane 5, DLD-1; Lane 6, WiDr; Lane 7, Colo 201; Lane 8, Colo 320; Lane 9, Sw 837). Size markers (Lane M) consist of 100-bp DNA ladder markers (Takara, Tokyo, Japan).

\section{DISCUSSION}

There is the expression of the ets family of genes during embryonic life, particularly in the intestine, and this expression is dramatically reduced in later fetal age (3). In our study, Ets-1 was not expressed in the normal colon epithelium nor in colorectal adenomas with low or moderate dysplasia. However, $44.4 \%(12 / 27)$ of adenoma with high grade dysplasia (Tis) and $84.4 \%(103 / 122)$ of total carcinomas overexpressed Ets-1 protein (Tables 1 and 2). In submucosal carcinomas (T1) Ets-1 expression was weak (41.2\% positive, $7 / 17$ ), but was enhanced in carcinomas over submucosa (T2-4) $(91.4 \%$ positive, 96/105) (Table2). And there was statistical correlation between Ets-1 expressions and invasive grade $(P<.0001)$. Therefore, the degree of Ets- 1 expression was correlated to the extent of colorectal carcinoma invasion. Multi-step carcinogenesis has been proposed for colorectal carcinoma, a theory that is generally accepted (28). These results suggest that ets- 1 has a role in the invasion of colorectal carcinoma, as one of the steps in carcinogenesis and in the development of invasive characteristics.

In adenoma with high grade dysplasia, Ets-1 expression was detected in $44.4 \%(12 / 27)$ of cases. Ets-1 was expressed only in the area with high grade dysplasia, but not in the area with moderate or low dysplasia. We reported previously that Ets-1 plays a role in tumor invasion (6-8). We suppose that the adenoma with high grade dysplasia has a higher degree of invasive activity than the adenoma with low or moderate grade dysplasia in the colorectum.

Poorly differentiated adenocarcinomas show invasive spreading histologically, and have a significantly poorer prognosis than well and moderately differentiated carcinomas (29). It has been reported that there was a significant correlation between the grade of histological differentiation and collagenolytic activity (30). However our results indicated no association between Ets-1 expression and tumor differentiation.

Tumor desmoplasia is a common feature in several malignant human tumors. It has been reported that a well-marked desmoplastic stromal reaction is associated with a poorer prognosis (31). Expression of MMP-1 that is regulated by Ets-1 has been observed in areas of extracellular matrix remodeling both in physiological and pathological situations (32). In our study, there were significant associations between Ets-1 immunoreactivity in carcinoma cells and the degree of desmoplastic stromal reaction $(P<.05)$. We supposed that Ets-1 played some roles in stromal remodeling through the expression of MMP-1.

In invasive carcinomas, Ets-1 immunoreactivity was significantly correlated with the presence of lymph node metastasis $(P<.05)$, lymphatic invasion $(P<.01)$ and venous invasion $(P<.05)$. Ordinarily, these results were understanded that the expression of Ets-1 induced the metastatic activity of carcinoma cells. However, in our study, the incidence of lymphatic invasion, venous invasion and lymph node metastasis increased with the depth of tumor invasion (data not shown). Therefore, we supposed that Ets-1 induced the deeper invasion of carcinoma cells, and that carcinoma cells infiltrated successively to lymph ducts and vein, and reached lymph nodes.

The product of ets-1 is localized in the nucleus and binds to DNA (33). However, in other reports, Ets-1 protein was detected in the cytoplasm (34) or both in the cytoplasm and in the nucleus in human colorectal carcinoma cell lines (35). In this study, we showed immunohistochemically that Ets-1 protein was widely expressed in the cytoplasm of carcinoma cells as well as in the nucleus. We believe that Ets-1 protein is overproduced in the cytoplasm and bound to DNA in the nucleus of colorectal carcinoma cells. Recently, it was shown that Ets-1 protein regulates the gene expression of some cytokines and peptides, such as Fos and Jun (36), integrin (37), stromelysin (38), u-PA (5) and MMP-1 (12). The expression of these substances also has been observed in colorectal carcinoma cells (3941 ), and they may play important roles in tumor invasion and progression.

It was necessary to determine whether Ets-1 is produced by mesenchymal cells or carcinoma cells. Ets-1 is thought to be involved not only in tumor invasion but in connective tissue remodeling (42). We observed increased Ets-1 expression during vascular smooth muscle cell migration and/or proliferation induced by serum stimulation in vitro and 
by balloon injury in vivo (18). Ets-1 is known to be expressed in stromal fibroblasts around carcinoma cells (43). The expression of the ets-1 gene also has been demonstrated in vascular sarcomas (44) and astrocytomas (45). In this study, however, we detected ets-1 mRNA in the colorectal carcinoma cells themselves, but not intensely in stromal fibroblasts, as shown by immunohistochemistry and in situ hybridization. RT-PCR of the ets-1 mRNA from the two human carcinoma tissues and the four carcinoma cell lines confirmed that it is produced in the carcinoma cells themselves, as we previously reported in carcinoma cells of the stomach (6), pancreas (7) and thyroid (8). These findings suggest that Ets-1 is expressed in carcinoma cells and we suppose that Ets-1 may play a critical role in the invasion of colorectal carcinoma cells.

The ets- 1 gene is localized to the q23 region of chromosome 11 and is translocated in certain leukemias and lymphomas (46). Recently, in colorectal carcinoma, loss of heterozygosity ( $\mathrm{LOH})$ of chromosome 11q23 has been reported (47), and it was suggested that the mutation of the ets-1 gene was concerned with the genesis of colorectal carcinoma. Although we did not examine the $\mathrm{LOH}$ of chromosome 11q23 in this study, it has reported that wild type Ets-1 suppresses tumorigenicity of human colon cancer cells, but variant Ets-1 did not suppress it (48). Therefore, we suggest that the overexpressed Ets-1 protein in colorectal carcinoma is a variant form of the wild type and that this variant type does not have the normal function of wild type Ets-1 as a p53 proto-oncogene product. Further studies are necessary for confirmation of this hypothesis.

In conclusion, our results suggest that ets- 1 plays a role or roles in the carcinogenesis and/or the progression of colorectal adenocarcinoma. The overexpression of the ets-1 proto-oncogene product may be one of the steps in the multi-step carcinogenesis of human colorectal carcinomas.

\section{REFERENCES}

1. Steinberg SM, Barwick KW, Stablein DM. Importance of tumor pathology and morphology in patients with surgically resected colon cancer. Findings from the Gastrointestinal Tumor Study Group. Cancer 1986;58:1340-5.

2. Leprince D, Gegonne A, Coll J, de Taisne C, Schneeberger A, Lagrou C, et al. A putative second cell-derived oncogene of the avian leukaemia retrovirus E26. Nature 1983;306:395-7.

3. Kola I, Brookes S, Green AR, Garber R, Tymms M, Papas T, et al. The Ets1 transcription factor is widely expressed during murine embryo development and is associated with mesodermal cells involved in morphogenetic processes such as organ formation. Proc Natl Acad Sci U S A 1993;90:7588-92.

4. Lewin B. Oncogenic conversion by regulatory changes in transcription factors. Cell 1991;64:303-12.

5. Vandenbunder B, Wernert N, Queva C, Desbiens X, Stehelin D. Does the transcription factor c-ets 1 take part in the reg- ulation of angiogenesis and tumor invasion? Folia Biol 1994; 40:301-13.

6. Nakayama T, Ito M, Ohtsuru A, Naito S, Nakashima M, Fagin JA, et al. Expression of Ets-1 proto-oncogene in human gastric carcinoma: correlation with tumor invasion. Am J Pathol 1996;149:1931-9.

7. Ito T, Nakayama T, Ito M, Naito S, Kanematsu T, Sekine I. Expression of ets-1 proto-oncogene in human pancreatic carcinoma. Mod Pathol 1998;11:209-15.

8. Nakayama T, Ito M, Ohtsuru A, Naito S, Nakashima M, Sekine I. Expression of the ets-1 proto-oncogene in human thyroid tumor. Mod Pathol 1999;12:61-8.

9. Liotta LA, Stetler-Stevenson WG. Metalloproteinases and cancer invasion. Semin Cancer Biol 1990;1:99-106.

10. Matrisian LM, Bowden TG. Stromelysin/transin and tumor progression. Semin Cancer Biol 1990;1:107-15.

11. Blasi F, Verde P. Urokinase-dependent cell surface proteolysis and cancer. Semin Cancer Biol 1990;1:117-26.

12. Nerlov C, De Cesare D, Pergola F, Caraccilo A, Blasi F, Johnsen $\mathrm{M}$, et al. A regulatory element that mediates cooperation between a PEA3-AP-1 element and an AP-1 site is required for phorbol ester induction of urokinase enhancer activity in HepG2 hepatoma cells. EMBO J 1992;11:4573-82.

13. Jass SR, Sobin LH. Histological typing of intestinal tumours. World Health Organization. 2nd ed. Berlin: Springer-Verlag; 1989.

14. Beahrs OH, Henson DE, Hutter RVP, Kennedy BJ, editors. Manual for staging of cancer. 4th ed. Philadelphia: Lippincott; 1992. p. 69-73.

15. Jass JR, Atkin WS, Cuzick J, Bussey HJ, Morson BC, Northover $\mathrm{JM}$, et al. The grading of rectal cancer: histological perspective and a multivariate analysis of 447 cases. Histopathology 1986;10:437-59.

16. Seefeld PH, Bargen JA. The spread of cancer of the rectum: invasion of the lymphatics, veins and nerves. Ann Surg 1943; 118:76-89.

17. Talbot IC, Ritchie S, Leighton M, Hughes AO, Bussey HJR, Morson BC. Invasion of veins by carcinoma of rectum: methods of detection, histological features and significance. Histopathology 1981;5:141-63.

18. Hultgardh-Nilsson A, Cercek B, Wang J-W, Naito S, Lovdahl C, Sharifi B, et al. Regulated expression of the ets-1 transcription factor in vascular smooth muscle cells in vivo and in vitro. Circ Res 1996;78:589-95.

19. Watson DK, McWilliams MJ, Lapis $P$, Lautenberger A, Schweinfest CW, Papas TS. Mammalian ets- 1 and ets-2 genes encode highly conserved proteins. Proc Natl Acad Sci U S A 1988;85:7862-6.

20. Otsuru A, Nagataki S, Koji T, Tamaoki T. Analysis of alphafetoprotein gene expression in hepatocellular carcinoma and liver cirrhosis by in situ hybridization. Cancer 1988;62: 1105-12.

21. Drewinko B, Romsdahl MM, Yang LY, Ahearn MJ, Trujillo JM. Establishment of a human carcinoembryonic antigenproducing colon adenocarcinoma cell line. Cancer Res 1976; 36:467-75.

22. Semple TU, Quinn LA, Woods LK, Moore GE. Tumor and lymphoid cell lines from a patient with carcinoma of the colon for a cytotoxicity model. Cancer Res 1978;38:1345-55.

23. Tsuiji H, Hayashi M, Wynn DM, Irimura T. Expression of mucin-associated sulfo-Lea carbohydrate epitopes on human colon carcinoma cells. Jpn J Cancer Res 1998;89:126775.

24. Tsuboi KK, Kwong LK. Antiproliferative agents and differential survival between normal and cancer cells. Cancer Res 1978;38:3745-50.

25. Hara A, Yoshimi N, Niwa M, Ino N, Mori H. Apoptosis induced by NS-398, a selective cyclooxygenase-2 inhibitor, 
in human colorectal cancer cell lines. Jpn J Cancer Res 1997;88:600-4.

26. Ohtaka K, Watanabe S, Iwazaki R, Hirose M, Seto N. Role of extracellular matrix on colonic cancer cell migration and proliferation. Biochem Biophys Res Commun 1996;220:346-52.

27. van Dekken H, Pizzolo JG, Kelsen DP, Melamed MR. Targeted cytogenetic analysis of gastric tumors by in situ hybridization with a set of chromosome-specific DNA probes. Cancer 1990;66:491-7.

28. Fearon ER, Vogelstein B. A genetic model for colorectal tumorigenesis. Cell 1990;61:759-67.

29. Newland RC, Chapuis PH, Pheils MT, MacPherson JG. The relationship of survival to staging and grading of colorectal carcinoma: a prospective study of 503 cases. Cancer 1981; 47:1424-9.

30. van der Stappen JWJ, Hendriks T, Wobbes T. Correlation between collagenolytic activity and grade of histological differentiation in colorectal tumors. Int J Cancer 1990; 45:1071-8.

31. Halvorsen TB, Seim E. Association between invasiveness, inflammatory reaction, desmoplasia and survival in colorectal cancer. J Clin Pathol 1989;42:162-6.

32. Matrisian LM. Metalloproteinases and their inhibitors in matrix remodeling. Trends Genet 1990;6:121-5.

33. Pognonec P, Boulukos KE, Ghysdael J. The c-ets-1 protein is chromatin associated and binds to DNA in vitro. Oncogene 1989;4:691-7.

34. Fujiwara S, Fisher RJ, Seth A, Bhat NK, Showalter SD, Zweig $\mathrm{M}$, et al. Characterization and localization of the products of the human homologs of the v-ets oncogene. Oncogene 1988; 2:99-103.

35. Koizumi S, Fisher RJ, Fujiwara S, Jorcyk C, Bhat NK, Seth A, et al. Isoforms of the human ets-1 protein: generation by alternative splicing and differential phosphorylation. Oncogene 1990;5:675-81.

36. Wasylyk B, Wasylyk C, Flores P, Begue A, Leprince D, Stehelin D. The c-ets proto-oncogenes encode transcription factors that cooperate with c-Fos and c-Jun for transcriptional activation. Nature 1990;346:191-3.

37. Rosen GD, Barks JL, Iademarco MF, Fisher RJ, Dean DC. An intricate arrangement of binding sites for the Ets family of transcription factors regulates activity of the alpha 4 integrin gene promoter. J Biol Chem 1994;269:15652-60.

38. Higashino F, Yoshida K, Noumi T, Seiki M, Fujinaga K. Ets-related protein E1A-F can activate three different matrix metalloproteinase gene promoters. Oncogene 1995;10:1461-3.

39. Nomura N, Yamamoto T, Toyoshima K, Ohami H, Akimaru $\mathrm{K}$, Sasaki S, et al. DNA amplification of the c-myc and c-erbB-1 genes in a human stomach cancer. Jpn J Cancer Res 1986;77:1188-92.

40. Fujita S, Suzuki H, Kinoshita M, Hirohashi S. Inhibition of cell attachment, invasion and metastasis of human carcinoma cells by anti-integrin beta 1 subunit antibody. Jpn J Cancer Res 1992;83:1317-26.

41. McDonnell S, Navre M, Coffey RJ Jr, Matrisian LM. Expression and localization of the matrix metalloproteinase pump-1 (MMP-7) in human gastric and colon carcinomas. Mol Carcinog 1991;4:527-33.

42. Liotta LA, Steeg PS, Stetler-Stevenson SWG. Cancer metastasis and angiogenesis: an imbalance of positive and negative regulation. Cell 1991;64:327-36.

43. Wernert N, Gilles F, Fafeur V, Bouali F, Raes M-B, Pyke C, et al. Stromal expression of c-Ets 1 transcription factor correlates with tumor invasion. Cancer Res 1994;54:5683-8.

44. Wernert N, Raes MB, Lassalle P, Dehouck MP, Gosselin B, Vandenbunder B, et al. c-ets1 proto-oncogene is a transcription factor expressed in endothelial cells during tumor vascularization and other forms of angiogenesis in humans. Am J Pathol 1992;140:119-27.

45. Amouyel P, Gegonne A, Delacourte A, Defossez A, Stehelin D. Expression of ETS proto-oncogenes in astrocytes in human cortex. Brain Res 1988;447:149-53.

46. Sacchi N, Watson DK, Guerts van Kessel AHM, Hagemeijer A, Kersey J, Drabkin HD, et al. Hu-ets-1 and Hu-ets-2 gene are transposed in acute leukemias with $(4 ; 11)$ and $(8 ; 21)$ translocations. Science 1986;231:379-82.

47. Gustafson CE, Young J, Leggett B, Searle J, Chenevix-Trench G. Loss of heterozygosity on the long arm of chromosome 11 in colorectal tumors. Br J Cancer 1994;70:395-7.

48. Suzuki H, Romano-Spica V, Papas TS, Bhat NK. ETS1 suppresses tumorigenicity of human colon cancer cells. Proc Natl Acad Sci U S A 1995;92:4442-6. 